\title{
STATUS EMOSIONAL DAN KUALITAS HIDUP PADA PASIEN MIASTENIA GRAVIS
}

\author{
*Tri Antika Rizki Kusuma Putri \\ *Sekolah Tinggi Ilmu Keperawatan PPNI Jawa Barat \\ Jl. Muhammad No. 34A Bandung 40173 \\ Telp. 022-6004498, 022-6121914, Fax.022-6121914 \\ Email:tri.antika90@gmail.com
}

\begin{abstract}
Abstrak
Miastenia gravis merupakan kelainan autoimun yang menyerang neurotransmitter di tautan neuromuskular dan menghambat terjadinya kontraksi di otot. Kelemahan otot yang terjadi menyebabkan keterbatasan aktivitas fisik serta terganggunya kesejahteraan psikologis dan interaksi sosial yang dapat mempengaruhi kualitas hidup pasien dengan miastenia gravis. Penelitian ini bertujuan untuk mengetahui hubungan antara status emosional dengan kualitas hidup pasien dengan miastenia gravis. Penelitian ini merupakan deskriptif analitik dengan menggunakan desain cross sectional. Sebanyak 75 pasien dengan miastenia gravis setuju untuk berpartisipasi dalam penelitian ini. Hasil penelitian menunjukan adanya hubungan yang signifikan antara status emosional dengan kualitas hidup pasien dengan miastenia gravis $(\mathrm{p}<0.05)$. Hasil dari penelitian ini akan membantu penelitian selanjutnya untuk mengembangkan tindakan keperawatan yang berfokus pada perbaikan status emosional sehingga kualitas hidup pasien dengan miastenia gravis dapat ditingkatkan.
\end{abstract}

Kata kunci: Kualitas hidup, miastenia gravis, status emosional

\begin{abstract}
Myasthenia gravis is an autoimmune disorder that affect neurotransmitter at neuromuscular junction wich inhibits contractions in the muscles. Muscle weakness occurs causing limitation of physical activity as well as the disruption of psychological well-being and patient's social interaction. This study aimed to determine the relationship between emotional status with quality of life of myasthenia gravis's patients. This research is a descriptive analytic with cross sectional design involving 75 patients. The results of this research showed a signofocant relationship between emotional status with quality of life of myasthenia gravis's patinets $(p<0.05)$. The results of this research will assist in conducting further research regarding nursing intervention for improving myasthenia gravis patient's quality of life.
\end{abstract}

Keywords: Emotional status, myasthenia gravis, quality of life 


\section{PENDAHULUAN}

Miastenia Gravis merupakan penyakit autoimun kronis yang menyerang area neuromuscular junction (NMJ) yang ditandai dengan menurunnya kemampuan otot dalam berkontraksi yang mengakibatkan terjadinya kelemahan [1]. Sebagian besar kasus Miastenia Gravis secara spesifik menyerang reseptor Acetylcholine (AChR) di area postsinaps dan komponen non-ACh lainnya seperti Muscle-Specific Receptor Kinase (MuSK) dan Lipoprotein-Related 4 (LRP4) $[2,3]$. Departemen kesehatan Amerika Serikat mencatat jumlah pasien miastenia gravis diestimasikan sebanyak 5 sampai 14 dari 100.000 orang populasi pada seluruh etnis maupun jenis kelamin [4]. Angka tersebut jauh berbeda dengan angka insidensi di wilayah Eropa seperti Inggris, Italia, dan Pulau Farou di Islandia yaitu sebesar 21-30 per 1.000.000 populasi [5]. Di Indonesia sendiri belum ditemukan data yang akurat terkait angka kejadian miastenia gravis. Yayasan Miastenia Gravis Indonesia (YMGI) selaku support group utama sampai saat ini masih mengupayakan pendataan yang maksimal terkait jumlah pasien dengan miastenia gravis di Indonesia.

Pasien dengan miastenia gravis berada pada semua kelompok usia dengan rata-rata usia ketika onset yakni 33-38 tahun [6]. Miastenia gravis terjadi pada semua jenis kelamin dengan perbandingan sebesar 2:3 antara lakilaki dan perempuan serta yang dikuatkan oleh hasil penelitian yang menunjukan jumlah kejadian yang terbilang sama [6].

Manifestasi klinis yang muncul pada miastenia gravis akibat gagalnya asetilkolin untuk berikatan dengan reseptor asetilkolin dapat berupa kelemahan otot dengan karakteristik tidak ada nyeri dan seringkali diperburuk dengan melakukan aktivitas [3].
Kelemahan otot yang terjadi pada pasien miastenia gravis menjadi salah satu faktor penting yang menentukan tingkat kesehatan baik fisik maupun mental [7]. Miastenia gravis termasuk penyakit yang mematikan dengan karakter progresif yakni semakin lama seiring berjalannya waktu maka kelemahan yang dapat ditimbulkan akan semakin luas [8]. Kasus terparah pada miastenia gravis membutuhkan pemantauan ketat tanda-tanda vital dikarenakan risiko terjadinya sesak napas akibat kelemahan otot inter costa dan diafragma terus meningkat [7].

Keseluruhan proses penyakit dan pengobatan tidak hanya berdampak pada sisi fisiologis namun sisi psikologis pasien pun dapat mengalami perubahan. Pasien dan keluarga seringkali mengalami respon psikososial seperti kecemasan, frustasi, marah, kebencian, ketakutan, penolakan, merasa bersalah, depresi, dan ketidakmampuan atau ketidakberdayaan [9]. Hal tersebut didukung dengan hasil penelitian sebelumnya yang melibatkan pasien dengan miastenia gravis di Jerman yang membuktikan bahwa adanya kelainan psikologis seperti depresi yang terjadi pada pasien miastenia gravis [7]. Hilang timbulnya gejala miastenia gravis serta fase akut dan kronis yang dialami oleh pasien menjadi penyebab munculnya kelainan psikologis dan emosional bagi pasien juga keluarga.

Berdasarkan studi kasus yang dilakukan pada pasien dengan miastenia gravis diketahui bahwa seorang pasien dengan miastenia gravis yang telah mengalami penurunan kondisi klinis berulang dapat menunjukan toleransi terhadap pemberian terapi namun hal ini menyebabkan frustasi sebagai dampak dari stress psikologis akibat ketergantungan terhadap konsumsi obat maupun penatalaksanaan medis lainnya seperti plasmaferesis [10]. Pasien miastenia gravis seringkali merasakan masalah emosional baik akibat 
gejala fisik maupun pengobatan penyakit. Pasien dengan gangguan neurologik akan mengalami gangguan neuropsikotik serta masalah emosional yang akhirnya akan mempengaruhi status fungsional dan kondisi klinis pasien secara keseluruhan [11].

Semua penyakit kronik, termasuk miastenia gravis, memiliki dampak psikologis dalam hal mekanisme koping dan juga kualitas hidupnya. Pernyataan tersebut dipertegas oleh penelitian di Serbia dan Thailand yang menunjukkan penurunan kualitas hidup baik aspek fisik maupun mental pada pasien miastenia gravis [12]. Penelitian lain yang melibatkan geriatrik dengan penyakit kronis menyebutkan adanya keinginan bunuh diri pada pasien sebagai salah satu dampak psikologis yang ditimbulkan oleh penyakit maupun perawatan [13]. Penelitian terkait status emosional pada pasien miastenia gravis masih terbatas pada melihat gambaran kejadian depresi, sedangkan penelitian berkaitan kualitas hidup pasien dengan miastenia gravis berfokus pada kondsi fisik dari pasien. Tujuan dari penelitian ini yaitu untuk mengetahui hubungan status emosional dan kualitas hiup pada pasien dengan miastenia gravis.

\section{METODE PENELITIAN}

Penelitian ini merupakan deskriptif analitik dengan design studi cross sectional. Sampel pada penelitian ini adalah pasien Miastenia Gravis yang berdomisili di Pulau Jawa sebanyak 88 responden dengan 13 orang drop out sehingga total pasien dengan miastenia gravis yang dilakukan analisa data lebih lanjut berjumlah 75 pasien. Penelitian ini menggunakan teknik pengambilan sampel Snowball Sampling yang diawali bekerjasama dengan YMGI dalam menentukan responden yang pertama dan selanjutnya penentuan responden selanjutnya berdasarkan informasi dari responden pertama. Adapun kriteria inklusi pada penelitian adalah; 1) Mengidap penyakit Miastenia Gravis yang ditandai dengan keanggotaan di Yayasan Miastenia Gravis Indonesia, 2) Berdomisili di area Pulau Jawa, 3) Kesadaran Compos Mentis. Kriteria Ekslusi; 1) Tidak memiliki gangguan kognitif yang mempengaruhi kemampuan berpikir. Gambaran karakteristik yang diteliti pada penelitian ini meliputi usia, jenis kelamin, lama menderita, status emosional meliputi; depresi, ansietas, dan stress, serta kualitas hidup responden.

\section{Instrumen}

Kuesioner untuk menilai status emosional yang dialami oleh responden dengan menggunakan kuesioner DASS 21. Instrumen DASS 21 merupakan instrumen baku yang telah digunakan secara luas dalam penelitian terkait kesejahteraan psikologis maupun psikodinamika. Instrumen ini memiliki 21 item pertanyaan yang terbagi menjadi tiga bagian atau sub variabel yakni depresi, ansietas, dan stress. Masing-masing pertanyaan terdiri dari 4 pillihan jawaban dengan rentang skor 0-3. Pada masing-masing bagian total skor akan dikalikan dua yang selanjutnya dikategorikan ke dalam 5 kategori yakni normal, gangguan ringan, sedang, berat, dan sangat berat. Semakin tinggi skor maka semakin besar gangguan yang dialami oleh responden.

Pengukuran kualitas hidup menggunakan instrumen MG-PRO. Kuesioner ini dikembangkan berdasarkan WHO-QOL sejak tahun 2012 dan digunakan sebagai alat ukur mandiri bagi pasien miastenia gravis [14]. Terdiri dari 53 item pertanyaan dengan 5 pilihan jawaban. Semakin tinggi skor maka semakin baik kualitas hidup pasien. Peneliti mengikutsertakan 15 pasien dengan miastenia gravis yang berdomisili di luar Jabodetabek dalam uji validitas dan reliabilitas. 
Berdasarkan hasil uji validitas dan reliabilitas yang dilakukan didapatkan hasil bahwa kuesioner MG-PRO memiliki nilai Cronbach Alpha di atas 0.8 dan dapat disimpulkan kuesioner MG-PRO reliabel atau konsisten dalam mengukur sumber dukungan sosial, bentuk dukungan sosial, dan kualitas hidup pasien miastenia gravis. Kuesioner MG-PRO memiliki total 53 item pertanyaan dan setelah dilakukan uji validitas terdapat 3 pertanyaan yakni item pertanyaan no 17,43 , dan 46 dinyatakan tidak valid dikarenakan memiliki nilai korelasi kurang dari 0.514. Sehingga ketiga item pertanyaan tersebut harus dikeluarkan dari kuesioner.

\section{Pengumpulan Data}

Pengumpulan data diawali dengan dilakukannya proses permohonan izin penelitian serta uji etik dari Universitas Indonesia. Selanjutnya, peneliti memberikan permohonan izin penelitian dari YMGI untuk meminta kerjasamanya dalam penentuan responden. Pada penelitian ini setiap responden diberikan penjelasan secara menyeluruh dan kesempatan untuk bertanya. Responden secara sukarela berpartisipasi pada penelitian dengan menandatangani lembar persetujuan atau informed concent. Peneliti memberikan kebebasan kepada calon responden untuk ikut serta maupun mengundurkan diri selama proses penelitian serta tidak memberikan sangsi apapun pada responden yang drop out atau mengundurkan diri.

Responden berhak memilih untuk mengisi kuesioner lewat email atau tatap muka langsung. Bagi responden yang memilih teknis pengisian lewat email untuk diisi oleh responden via email pribadi. Peneliti memberikan waktu 2 hari untuk pengisian kuesioner pada hari keempat akan dilakukan follow up kepada masing-masing responden yang telah dikirim email. Pemberian kuesioner disertai dengan tata cara pengisian untuk masing-masing kuesioner dan peneliti menyertakan nomor kontak peneliti agar dapat dihubungi langsung oleh responden untuk menanyakan item pertanyaan yang belum dipahami. Bagi responden yang mengisi kuesioner secara tatap muka langsung, pengisian kuesioner langsung diisi seluruhnya dengan estimasi waktu 30-45 menit.

\section{Analisis Data}

Pengolahan data dilakukan melalui 4 (empat) tahapan yaitu editing, coding, processing, dan cleaning. Analisa data terdiri dari analisis univariat untuk mengidentifikasi gambaran karakteristik pada responden. Pada data numerik, analisis bertujuan untuk melihat nilai mean, median, modus, standar deviasi, nilai minimal, nilai maksimal serta confident interval (CI 95\%). Sedankan pada data kategorik dilihat distribusi frekuensi serta proporsi dari variabel yang diteliti.

Analisis bivariat bertujuan untuk melihat hubungan antara variabel independen (status emosional) dengan variabel dependen (kualitas hidup pasien dengan miastenia gravis). Uji statistik yang digunakan pada uji bivariate menggunakan One Way ANOVA.

\section{HASIL PENELITIAN}

Deskripsi uji analisis univariat untuk data kategorik yakni jenis kelamin dan status emosional (depresi, ansietas, dan stress) ditampilkan dalam bentuk proporsi, sedangkan untuk data numerik yakni usia, lama menderita, dan kualitas hidup ditampilkan dalam bentuk mean, median, minimum-maksimum, dan standar deviasi dengan confidence interval 95\%. Hasil analisis univariat yang diperoleh adalah sebagai berikut: 
Tabel 1.

Distribusi Responden Berdasarkan Jenis Kelamin dan Status Emosional (n:75)

\begin{tabular}{llcc}
\hline & \multirow{2}{*}{ Variable } & \multicolumn{2}{c}{ Uraian } \\
\cline { 3 - 4 } Jenis Kelamin & Laki-laki & $(\boldsymbol{n})$ & $(\%)$ \\
& Perempuan & 20 & 26.7 \\
Status Emosional & & 55 & 73.3 \\
\cline { 3 - 4 } Depresi & Normal & 32 & 42.7 \\
& Ringan & 8 & 10.7 \\
& Sedang & 11 & 14.7 \\
& Berat & 4 & 5.3 \\
& Sangat Berat & 20 & 26.7 \\
\hline Ansietas & Normal & 14 & 18.7 \\
& Ringan & 3 & 4.0 \\
& Sedang & 8 & 10.7 \\
& Berat & 7 & 9.3 \\
& Sangat Berat & 43 & 57.3 \\
\hline Stres & Normal & 23 & 30.7 \\
& Ringan & 9 & 12.0 \\
& Sedang & 12 & 16.0 \\
& Berat & 15 & 20.0 \\
& Sangat Berat & 16 & 21.3 \\
\hline
\end{tabular}

Hasil analisis statistik menunjukkan bahwa sebagian besar responden berjenis kelamin perempuan dengan persentase sebesar 73.3\%. Sejalan dengan hasil penelitian sebelumnya, disebutkan bahwa miastenia gravis dapat terjadi pada semua kelompok usia baik laki-laki maupun perempuan dengan perbandingan antara perempuan dan laki-laki 3:2 [15]. Sebuah penelitian menyebutkan bahwa miastenia gravis lebih sering terjadi pada perempuan pada semua kelompok etnis (Afrikan, Asia, Amerika, dan Kaukasian) [16]. Selain itu, tingginya angka kejadian pada perempuan dibanding laki-laki dapat berhubungan dengan karakteristik miastenia gravis yang pada sebagian besar kasus menyerang individu pada kelompok usia dewasa muda dan pada rentang usia ini, perempuan lebih banyak terserang [17].

Pada analisis status emosional, peneliti membagi variabel tersebut menjadi tiga yakni depresi, ansietas, dan stress. Sebagian besar responden tidak menunjukkan gejala depresi (42.7\%), namun pada responden yang menunjukkan gejala depresi sebagian besar berada pada kategori depresi sangat berat (26.7\%). Ansietas yang ditunjukkan oleh responden sebagian besar dalam kategori sangat berat (57.3\%). Sebagian besar responden menunjukkan stress dalam rentang normal (30.7\%).

Tabel. 2.

Distribusi Responden Berdasarkan Usia, Lama Menderita, Kualitas Hidup (n:75)

\begin{tabular}{llllll}
\multicolumn{1}{c}{ Variabel } & \multicolumn{1}{c}{ Mean } & \multicolumn{1}{c}{ Median } & \multicolumn{1}{c}{ SD } & \multicolumn{1}{c}{ Min-Maks } & \multicolumn{1}{c}{ 95\% CI } \\
\hline Usia & 36.39 & 35.00 & 11.754 & $18-75$ & $33.68-39.09$ \\
\hline Lama Menderita & 6.80 & 6.00 & 4.986 & $1-22$ & $5.65-7.95$ \\
\hline Kualitas Hidup & 178.35 & 179.00 & 33.457 & $91-247$ & $170.65-186.04$ \\
\hline
\end{tabular}


Hasil analisis pada tabel 2. menunjukkan rerata usia responden yaitu 36.39 tahun (95\% CI 33.6839.09) dengan standar deviasi 11.754. Usia termuda yaitu 18 tahun dan usia tertua 75 tahun. Sedangkan rata-rata lama menderita miastenia gravis pada responden yakni 6.80 tahun (95\% CI 5.65-7.95) dengan standar deviasi sebesar 6.00. Lama menderita miastenia gravis terendah yaitu satu tahun dan tertinggi selama 22 tahun.

Tabel 2. juga menunjukan distribusi responden berdasarkan variabel dependen kualitas hidup yang diukur dengan menggunakan kuesioner MG-PRO. Berdasarkan uji statistik didapatkan rata-rata nilai kualitas hidup pada responden adalah sebesar 178.35 dengan standar deviasi sebesar 34.457 (95\% CI 170.65-186.04). Skor terendah pada kualitas hidup responden yakni 91 dan skor tertinggi sebesar 247.

Tabel 3.

Hubungan Status Emosional Terhadap Kualitas Hidup

Pasien Miastenia Gravis (n: 75)

\begin{tabular}{lllll}
\hline \multicolumn{1}{c}{ Variabel } & Mean & \multicolumn{1}{c}{ SD } & \multicolumn{1}{c}{ 95\% CI } & P value \\
\hline Depresi & & & & \\
$\quad$ Normal & 198.81 & 30.813 & $186.63-211.00$ & \\
Ringan & 167.75 & 41.890 & $132.73-202.77$ & $0.001^{*}$ \\
Sedang & 171.40 & 28.096 & $151.30-191.50$ & \\
Berat & 166.75 & 9.708 & $151.30-182.20$ & \\
$\quad$ Sangat Berat & 158.88 & 29.255 & $143.29-174.46$ & \\
\hline Ansietas & & & & \\
$\quad$ Normal & 215.17 & 27.729 & $197.55-232.78$ & \\
Ringan & 214.00 & 22.627 & $10.70-417.30$ & $0.000^{*}$ \\
Sedang & 191.83 & 25.787 & $164.77-218.90$ & \\
Berat & 177.00 & 10.512 & $163.95-190.05$ & \\
Sangat Berat & 164.68 & 30.537 & $154.91-174.44$ & \\
\hline Stress & & & & \\
$\quad$ Normal & 205.11 & 30.447 & $189.97-220.25$ & \\
Ringan & 163.00 & 25.906 & $141.34-184.66$ & $0.02 *$ \\
Sedang & 184.27 & 29.625 & $164.37-204.17$ & \\
Berat & 168.47 & 32.989 & $150.20-186.74$ & \\
Sangat Berat & 160.50 & 29.273 & $143.60-177.40$ & \\
\hline
\end{tabular}

*Hubungan signifikan pada $\mathrm{p}<0.05$

Uji statistik ANOVA membuktikan bahwa antara variabel status emosional-depresi dengan kualitas hidup memiliki $p$ value $=0.001$ sehingga dapat disimpulkan bahwa terdapat hubungan yang signifikan anatara kategori depresi yang dialami oleh responden dengan kualitas hidup. Berdasarkan hasil uji statistik yang dicantunkam dalam tabel III, diketahui pula bahwa antara variabel status emosionalansietas dengan kualitas hidup memiliki $p$ value $=0.000$ sehingga dapat disimpulkan bahwa terdapat hubungan yang signifikan pada masing-masing kategori ansietas yang dialami oleh responden dengan nilai kualitas hidup. Hasil uji analisis menunjukkan bahwa antara variabel status emosional-stress dengan kualitas hidup memiliki $p$ value $=0.002$ sehingga dapat disimpulkan bahwa terdapat hubungan yang signifikan pada masingmasing kategori stress yang dialami oleh responden dengan nilai kualitas hidup.

\section{PEMBAHASAN}

Status emosional dalam penelitian ini terbagi menjadi tiga, yakni depresi, ansietas, dan 
stress. Hasil analisis univariat menunjukkan $24.6 \%$ responden mengalami depresi sangat berat, sebagian besar responden mengalami ansietas sangat berat $(61.5 \%)$, dan sebagian besar responden $(21.5 \%)$ memiliki stress berat dan sangat berat $(n=65)$. Hasil bivariat diketahui bahwa terdapat hubungan yang signifikan di antara kelompok pada variabel status emosional baik depresi, ansietas, maupun stress terhadap nilai kualitas hidup pada pasien dengan miastenia gravis.

Gejala psikologis seringkali muncul pada pasien-pasien dengan gangguan neurologi atau persarafan. Tidak hanya aspek fisik pada pasien miastenia gravis yang mengalami penurunan fungsi namun begitu pula dengan status emosional pasien [9]. Sejalan dengan pernyataan tersebut, penelitian lain menyebutkan bahwa pada pasien miastenia gravis seringkali ditemukan berbagai gangguan psikologis seperti kecemasan maupun depresi [20]. Lebih lanjut dijelaskan bahwa masalah psikologis pada pasien miastenia gravis akan mempengaruhi kualitas hidup pasien dan keluarga serta meningkatkan angka mortalitas dan morbiditas [20]. Pada penelitian terkait kualitas hidup pasien miastenia gravis ditemukan bahwa ansietas dan depresi merupakan faktor-faktor yang mempengaruhi nilai kualitas hidup pasien [21]. Lebih lanjut dijelaskan bahwa penatalaksanaan depresi pada pasien akan meningkatkan kesejahteraan umum (fisik, psikologis, sosial) dari pasien, sebaliknya kondisi depresi secara signifikan berhubungan dengan rendahnya kualitas hidup terutama pada domain fisik dan psikologis. Depresi, ansietas, dan gejala fisik dari nyeri maupun ketidaknyamanan secara signifikan berhubungan dengan rendahnya kualitas hidup pada seorang individu [22].

Ansietas atau kecemasan merupakan masalah psikologis yang seringkali terjadi pada masyarakat. Peplau (1963) membagi kecemasan menjadi 4 tingkatan yakni ringan, sedang, berat, dan panik. Kecemasan ringan akan adaptif dan memotivasi individu untuk dapat bertahan dan akan menjadi masalah ketika kecemasan mengganggu kebutuhan dasar individu [24].

Sebagai salah satu penatalaksanaan farmakologi yang seringkali diberikan pada pasien miastenia gravis, prednisone sebagai kombinasi dengan pemberian asetilkolinerase memiliki beberapa efek samping [25]. Pemberian prednisone sebagai salah satu bentuk dari kortikosteroid dalam jangka waktu yang lama berhubungan dengan kejadian ansietas atau kecemasan serta depresi sedangkan dalam penggunaan jangka pendek dapat menyebabkan euphoria [20]. Regulasi dosis obat, kombinasi terapi, dan terapi konseling dibutuhkan oleh pasien miastenia gravis agar terhindar dari masalah psikologis.

Pada penelitian yang dilakukan terhadap 42 pasien miastenia gravis ditemukan hubungan antara stress dan juga kejadian kekambuhan penyakit yakni sebesar 35\% kejadian [20]. Hal ini diungkapkan karena tingkat depresi yang tinggi serta rasa tidak aman sebagai dampak dari penyakit dan sebagian besar merupakan responden perempuan. Lebih lanjut lagi, disebutkan bahwa pada pasien dengan riwayat krisis miastenik mengalami seringkali mengalami gangguan psikologis. Hal ini berkaitan dengan pengalaman pasien dalam melewati masa yang mengancam jiwa akibat menurunnya fungsi pernapasan yang secara tiba-tiba.

Pada sebuah penelitian di Thailand terkait status emosional pada pasien miastenia gravis didapatkan hasil bahwa status emosional pasien dengan miastenia gravis memiliki nilai yang lebih rendah apabila dibandingkan dengan penduduk Thailand normalnya [26]. 
Lebih lanjut dalam penelitiannya disebutkan bahwa menurunnya kesejahteraan emosional pada pasien miastenia gravis seringkali dihubungkan dengan terganggunya aktivitas rutin pasien seperti bekerja, pekerjaan rumah (household), maupun sekolah. Lewat cara pandang pasien, gejala-gejala yang ditimbulkan oleh miastenia gravis memiliki dampak yang besar kepada fungsi fisik serta emosional yang dapat terjadi akibat budaya dan status ekonomi sosial.

Hasil karakteristik usia pada penelitian ini menunjukan hasil yang kurang lebih sama dengan rentang usia pasien miastenia gravis pada pertama kali onset yakni berkisar antara 33-38 tahun [6]. Hal ini sejalan dengan penelitian cross sectional mengenai gambaran kualitas hidup pada pasien miastenia gravis di Brazil yang sebagian besar respondennya berusia di bawah 50 tahun [18]. Pada penelitian miastenia gravis lainnya didapatkan data bahwa penyakit ini memiliki angka insidensi tertinggi pada wanita dalam rentang usia 35-44 tahun [19].

\section{KESIMPULAN}

Kualitas hidup bukan merupakan diagnosa keperawatan namun merupakan salah satu indikator keberhasilan dalam pemberian intervensi keperawatan bagi pasien miastenia gravis. Minimnya pengkajian terkait status emosional pada pasien di layanan kesehatan seringkali membuat aspek psikologis termasuk didalamnya status emosional khususnya pada pasien miastenia gravis tidak terkaji. Perlunya pengkajian status emosional pada pasien dibutuhkan di pusat layanan kesehatan. Kolaborasi perawat ruangan dengan perawat spesialis keperawatan jiwa diharapkan dapat dilakukan guna meminimalisir dampak psikologis dari penyakit serta menyiapkan pasien ketika keluar dari pusat layanan kesehatan.
Diharapkan data pada penelitian ini dapat menjadi acuan dalam memberikan intervensi keperawatan yang dapat meningkatkan kualitas hidup pasien miastenia gravis.

\section{DAFTAR PUSTAKA}

[1] Ropper, A. H., Samuels, M. A., \& Klein, J. P. (2014). Adams and Victor's Principles of neurology (tenth edit). New york: Mc Graw Hill Education.

[2] Berrih-aknin, S., \& Panse, R. le. (2014). Myasthenia gravis: A comprehensive review of immune dysregulation and etiological mechanisms. Journal of Autoimmunity, 52, 90-100. http://doi.org/ 10.1016/j.jaut.2013.12.011

[3] Hickey, joanne V. (2014). The clinical Practice of neurological and neurosurgical nursing (seventh ed). Philadelphia: Lippincott Williams \& Wilkins.

[4] Penn, A. s, \& Kaminski, henry j. (2008). myasthenia gravis. US Department of Health and Human Services.

[5] Joensen, P. (2014). Myasthenia gravis incidence in a general North Atlantic isolated population.

[6] Myasthenia Gravis Association of Western Pennsylvania. (2009). Ocular Myasthenia Gravis.

[7] Twork, S., Wiesmeth, S., Klewer, J., Pöhlau, D., \& Kugler, J. (2010). Quality of life and life circumstances in German myasthenia gravis patients. Health and Quality of Life Outcomes, 8, 1-10.

[8] Corwin, elizabeth J. (2008). handbook of pathophysiology (third edit). Philadelphia: Lippincott Williams \& Wilkins.

[9] Woodward, S., \& Mestecky, A. (2011). neroscience nursing evidence-based practice. (S. Woodward \& A. Mestecky, Eds.). chichester: wiley-blackwell. 
[10] Dyar, K. L. (2013). Therapeutic plasma exchange in a patient with myasthenia gravis. Nephrology Nursing Journal, 40(6), 545-548.

[11] Barrett, A. M. (2010). Rose-colored answers : Neuropsychological deficits and patient-reported outcomes after stroke. Behavioural Neurology, 22, 17-23. http://doi.org/10.3233/BEN-2009-0250

[12] Basta, I. Z., Pekmezovic', T. D., Peric', S. Z., Kisic'-Tepavčevic', D. B., Lavrnic, D. V., Rakoc 'evic'-Stojanovic', V. M., \& Stevic', Z. D. (2012). Assessment of health-related quality of life in patients with myasthenia gravis in Belgrade ( Serbia ). Neurol Sci, (33), 1375-1381. http://doi.org/10.1007/s10072 $-012-1170-2$.

[13] Kim, S. H. (2016). Suicidal ideation and suicide attempts in older adults: Influences of chronic illness, functional limitations, and pain. Geriatric Nursing, 37(1), 9-12. http://doi.org/10.1016/j. gerinurse.2015.07.006.

[14] Li, feng bin, Chen, X., Guo, L., \& Liu, X. (2012). Evaluation of A Scale of Patient-Reported Outcomes for the Assessment of Myasthenia Gravis Patients in China. Chin J Integr Med, 18(10). http://doi.org/10.1007/s11655-011-09443.

[15] Guo, J., Dang, D., Li, H., \& Li, Z. (2014). Current overview of myasthenia gravis and experience in China. Neuroimmunal Neuroinflammation, 1(3), 127-130. http://doi.org/10.4103/23478659.143664

[16] Abukhalil, F., Mehta, B., Saito, E., Mehta, S., \& Mcmurtray, A. (2015). Gender and Ethnicity Based Differences in Clinical and Laboratory Features of Myasthenia Gravis. Hindawi Publishing Corporation Autoimmune Diseases, 2015.
[17] Oger, J., \& Frykman, H. (2015). An update on laboratory diagnosis in myasthenia gravis. Clinica Chimica Acta, 449, 43-48. http://doi.org/10.1016/j.cca.2015.07.030

[18] Mourão, A. M., Araújo, C. M., Barbosa, L. S. M., Gomez, R. S., Burns, T. M., Lemos, S. M. A., \& Teixeira, A. L. (2013). Brazilian cross-cultural translation and adaptation of the "Questionnaire of Life Quality Specific for Myasthenia Gravis - 15 items ." Arq Neuropsiquiatr, (January), 955-958.http://doi.org/10.1590 /0004-282X20130180.

[19] Breiner, A., Widdifield, J., Katzberg, H. D., Barnett, C., Bril, V., \& Tu, K. (2016). Epidemiology of myasthenia gravis in Ontario , Canada. Neuromuscular Disorders, 26(1), 41-46. http://doi.org/10.1016/j.nmd.2015.10.009

[20] Kulaksizoglu, I. B. (2007). Mood and Anxiety Disorders in Patients with Myasthenia Gravis Aetiology, Diagnosis and Treatment. CNS Drugs, 21(6), 473481.

[21] Kumar, R., Nagappa, M., Sinha, S., Taly, A. B., \& Rao, S. (2016). MG-QoL15 scores in treated myasthenia gravis: Experience from a university hospital in India. Neurology India. http://doi.org/ 10.4103/0028-3886.181542.

[22] Olisah, V. O., Baiyewu, O., \& Sheikh, T. L. (2011). Depression underdiagnosis and the effects on quality of life in outpatients with HIV at a Nigerian university teaching hospital. African Journal of AIDS Research, 10(3), 247254.

http://doi.org/10.2989/16085906.2011.626 294

[23] Huhes, J., Jelsma, J., Maclean, E., Darder, M., \& Tinise, X. (2004). The health-related quality of life of people 
living with HIV/AIDS. Disability and Rehabilitation 26(6), pp.371-376.

[24] Townsend, M.C. (2009). Psychiatric Mental Health Nursing: Concepts of Care in Evidence-Based Practice. Six edition. Philadelphia: FA Davis Company

[25] Toyka, K. V., \& Gold, R. (2007). Treatment of myasthenia gravis. Scweizer Archiv for Neurologie Und Psychiatrie, 309-321.
[26] Kulkantrakorn, K., Sawanyawisuth, K., \& Tiamkao, S. (2010). Factors correlating quality of life in patients with myasthenia gravis. Neurol Sci, (31), 571573. http://doi.org/10.1007/s10072-0100285-6 